\title{
PAUL L. BEAUBIEN, 1903-1962
}

\section{Charlie R. Steen}

E ARLY in the morning of July 8,1962, Paul L. Beaubien died suddenly and unexpectedly of a heart attack in his home in Omaha, Nebraska. At the time he was Regional Archeologist for the Midwest Region, National Park Service.

Paul Beaubien was born July 26, 1903, at Ford, Kansas. His father, a farmer, moved the family shortly thereafter to Prowers County, Colorado, where Paul spent his boyhood. He graduated from the high school at Lamar, Colorado, and in 1922-23 attended Kansas Agricultural and Mechanical College at Manhattan, Kansas. He then dropped his studies for some time until, in 1927, after several visits to the Colorado Museum of Natural History in Denver, a latent interest in both paleontology and archaeology was aroused. Rather characteristically, he went to the Director of the Museum, told him that "all that stuff looked interesting," and asked if he could get a job after he had gone to a university to study paleontology and archaeology. Upon being assured that there were jobs in those fields, he entered the University of Denver and began his studies.

During this period he was probably more interested in paleontology than in archaeology. As no courses in paleontology were offered at the University of Denver, he majored in anthropology. Paul worked part time at the Museum (now the Denver Natural History Museum) and became a close friend of the late Carl Schwachheim, one of the discoverers of the Folsom site and also a protégé of Harold Cook. He worked with the Museum off and on from 1929 to 1934 and excavated paleontological specimens in Colorado, New Mexico, and Oklahoma, as well as helping in the preparatorial department. In 1930 he was with the University of Denver archaeological survey of eastern Colorado and the following year was with the same institution on a survey of Wyoming. He received the A. B. degree from the University of Denver in 1930 and a Master of Arts degree in 1931.
In 1934 Beaubien joined the staff of the National Park Service. He served both as Archeologist (he excavated the Convento area at Tumacacori National Monument) and in an administrative capacity as Custodian of both Walnut Canyon and Saguaro National monuments. From 1949 until his death, his position was Regional Archeologist in Omaha, where his principal concern was with the archaeological salvage program in the Missouri Basin.

Paul was an exceptionally shy and retiring person who often hid his shyness under a brusque manner. He carried on only a few small excavations and, like many of us, suffered from a reluctance to write the results of his digging. What he did write, however, was clearly and forcibly stated.

His wife, Lois Baldwin Beaubien, survived him only a short time. She had been in ill health for several years and died in her sleep during November, 1962.

\section{Publications of Paul L. Beaubien}

1935 Notes on Tumacacori Excavations. Southwestern Monuments Monthly Report, January, 1935, pp. 44-8. Coolidge, Arizona.

1937 Excavations at Tumacacori, 1935. Southwestern Monuments Monthly Report, Supplement for March, 1937, pp. 183-220. Coolidge, Arizona.

1938 Nature Trail Operation. Southwestern Monuments Monthly Report, Supplement for July, 1938, pp. 81-6. Coolidge, Arizona.

1952 Preliminary Notes on an Archeological Project in Northeastern Iowa. Journal of the Iowa Archaeological Society, Vol. 1, No. 3. McGregor, Iowa.

1953 Cultural Variation within Two Woodland Mound Groups of Northeastern Iowa. American Antiquity, Vol. 19, No. 1, pp. 56-66. Salt Lake City.

1953 Some Hopewellian Mounds at the Effigy Mounds National Monument. The Wisconsin Archeologist, Vol. 34, No. 2. Milwaukee.

1957 Notes on the Archeology of Pipestone National Monument. The Minnesota Archeologist, Vol. 21, No. 3, pp. 1-17. St. Paul.

National Park Servich

Santa Fe, New Mexico

October, 1963 